\title{
China and Peaceful Settlement of Cambodian Issues
}

\author{
Qianyun Yang \\ Humanistic School, Qujing Normal University \\ Qujing 655011, Yunnan, China \\ E-mail: yangqianyun111@163.com
}

Foundation Item: The Scientific and Research Foundation Item in Office of Education in Yunnan Province "Study on Relationship between Japan and Southeast Asia during the Cold War" (6Y0146E)

\begin{abstract}
Because of the implementation of global strategy by Soviet Union and the expansion of regional hegemonism of Vietnam, some Cambodian issues came into being at the end of 70s in the Twentieth Century. As a regional great nation, China positively supported the war of anti-Vietnam and self-defense of Cambodia and united the other permanent member states of the United Nations Security Council as well as the Association of Southeast Asian Nations to facilitate the peaceful settlement of Cambodian issues, and so maintained the peace and security of Asia.

Keywords: China, Cambodian issues, Peaceful settlement

Chinese and Cambodian people have established solid friendship in the long run historical development. In April 1975 when the old generation of proletarian revolutionaries Mao Zedong, Zhu De \& Zhou Enlai congratulated Cambodian people's emancipation of Phnom Penh with armed forces, they said, "Chinese and Cambodian people are as intimate as brothers... Our brothers, Cambodian people have reasons to believe that, in any war in the future, Chinese people will always stand together with you and go forward together." At the end of 1978, Vietnam suddenly attacked Cambodia and launched the war of invasion in Cambodia. Thus, the world-shaking Cambodian issues appeared. In order to resolve Cambodian issues, the Chinese Government insisted on the diplomatic idea of "upholding justice and opposing hegemonism" advocated by Deng Xiaoping, and took a positive attitude in supporting the anti-Vietnamese War by Cambodian people, which finally facilitated the peaceful settlement of Cambodian issues.
\end{abstract}

\section{Support of Chinese Government in the Anti-Vietnamese War by Cambodia}

On December 25, 1978, Vietnam invaded Cambodia. In face of the aggression behavior of hegemonism in Vietnam, the Chinese Government made a positive response.

First of all, the Chinese Government morally supported the Anti-Vietnamese War of Cambodian people. After Vietnamese aggression, Head of Standing Committee of the National People's Congress of China, Ye Jianying, wrote a letter in reply to Khieu Samphan, President of the Presidium of Democratic Cambodia, saying, "the Chinese Government and Chinese people are in total support of the solemn and just standpoint expressed by you in the letter on behalf of the Democratic Cambodian Government, and we are resolutely in support of the just war by Cambodian people to oppose Vietnamese expansionists' aggression." This demonstrated the standpoint of Chinese people to oppose Vietnamese invaders and to support the just struggle of Cambodian people. On January 7, 1979, China made a government statement, "We are in support of the just war by Cambodian Government and its people to fight against Vietnamese aggression", and "we are in support of the rational proposal by the Cambodian Government to ask for an emergency meeting by the Security Council and for intervention by the United Nations." At the same time, Chinese Government revealed the purpose and essence of Vietnamese aggression in Cambodia, "as is well known, the frantic aggression in Cambodia by Vietnamese authority was to serve for the strategic plan of expansionism of Russia. Vietnam resorted to armed forces to attempt to embezzle Cambodia and to establish the so-called 'Indo-Chinese Federation' controlled by itself, which was an important procedure to enforce local hegemonism and also was an important component for Russia to contend for the strategy of hegemony in Asia and Far East." In February 1982, Zhao Ziyang, the Premier of the State Council of China, reaffirmed at the banquet to welcome the Democratic Cambodian Delegation headed by Khieu Samphan, the Chinese Government and Chinese people would run true to form support the just war of Cambodian people to resist Vietnamese aggression until its ultimate victory. Zhao Ziyang also gave a high evaluation on the 
anti-Vietnamese war by Cambodian people, "victory by Cambodian soldiers and civilians has not only defended its own independence and subsistence of the nation, but also has made significant contributions to holding back the aggression and expansion by Russia and Vietnam and maintaining peace and security in Southeast Asia and Pacific regions." On April 28, 1986, Chinese President Li Xiannian sent a telegram to Norodom Sihanouk after Coalition Government of Democratic Kampuchea proposed the eight suggestions to resolve Cambodian issues, expressing support to the anti-Vietnamese war by Cambodian people and the eight suggestions by the Coalition Government of Democratic Kampuchea to politically resolve Cambodian issues. Li Xiannian said, "Chinese Government and Chinese people will unswervingly support the just war of Cambodian people to save the country and resist Vietnam, and sincerely support the correct standpoint of the Coalition Government of Democratic Kampuchea in the eight suggestions about political settlement of Cambodian issues. Furthermore, China will make joint efforts with all countries and people in the world that love peace and uphold justice to request Vietnam to withdraw troops from Cambodia and to plow the soil for political settlement of Cambodian issues at an early date." At the end of July 1989, at the meeting held in Paris presided by the United Nations, Qian Qichen, Head of the Chinese delegation, made a speech, "China appreciates the international meeting held in Paris, would like to make efforts for peaceful settlement of Cambodian issues, and seek for comprehensive, just and rational political settlement of Cambodian issues that have been existing for as long as ten years." Support and affirmation by the Chinese people to anti-Vietnamese war by Cambodian people brought huge confidence and power to Cambodian people.

Then, China facilitated solidarity and cooperation of the three patriotic powers in Democratic Cambodia and aided the Coalition Government of Democratic Kampuchea. After Vietnam invaded Cambodia, they overthrew Pol Pot's regime and supported Heng Samrin's regime of "People's Republic of Kampuchea". Simultaneously, the following three parties continued to launch the anti-Vietnam War: "Khmer People's National Liberation Front" led by Son Sann, "National United Front for an Independent, Neutral, Peaceful and Co-operative Cambodia" led by Norodom Sihanouk and the Democratic Cambodia headed by Khieu Samphan. Since the three parties accumulated too much rancour, they did not trust each other. In order to encourage solidarity and cooperation of the three parties, Deng Xiaoping interviewed Norodom Sihanouk, Son Sann and Khieu Samphan for several times, asking them to strengthen solidarity, resist the enemy together and set up a coalition government. On June 22, 1982, under impelling by China and ASEAN, etc, the three parties of resistance forces in Cambodia held a conference in Malasia, and formally set up "the Coalition Government of Democratic Kampuchea". Norodom Sihanouk held the position of President, Khieu Samphan held the position of vice President and was responsible for diplomacy, and Son Sann held the position of Prime Minister. The tenet of the Coalition Government of Democratic Kampuchea was to "mobilize all power and fight together to emancipate Cambodia from Vietnamese invaders so as to recover the sovereignty and independence of the nation," and to "implement manifesto of the international conferences about Cambodian issues and other resolutions related with United Nations conference." After the establishment of the Coalition Government of Democratic Kampuchea, Chinese Government gave immediate acknowledgement to it and appointed Shen Ping, the Chinese Ambassador in Thailand, to succeed the position of Chinese Ambassador in Cambodia. Since Shen Ping was mainly responsible for Sino-Thai relations, Cambodian issues were assigned to Zhang Qing. In August 1982, Shen Ping submitted the letter of credence to the President Norodom Sihanouk.

After establishment of the Coalition Government of Democratic Kampuchea, the Chinese Government and the government signed an agreement of nonreimbursable assistance and strengthened military aid to the three parties of Cambodia. In order to support the war to save Cambodia, Chinese government leaders took measures to cooperate with Thailand. The Chinese Government sent in succession Geng Biao, Vice Prime Minister in charge of military task, and Huang Hua, Foreign Minister, to go to Thailand. In return, Thai Defense Minister and Foreign Minister also visited China. the two parties signed a cooperation agreement after interview for several times, and finally decided to assign it to China to send weapons and goods and materials for refugees to Thai ports by sea, then let Thai troops send them to the frontier of Thailand and Cambodia by land, which would finally reach the three military organizations of the three parties of Cambodia.

Finally, China launched a self-defense war to teach Vietnam a lesson. On February 14, 1979, the Central Committee of the Communist Party of China issued "the notice of self-defense war fighting to defend the frontier", which said, "the purpose of our self-defense war is to seek for peace and stability in border areas in China so as to guarantee the successful progress of the four modernizations. Area, time and scale of the war are all extremely limited." Since February 17, 1979, Chinese frontier forces launched an attack in Longzhou and Jingxi of Guangxi in China, and Hekou and Jinping in Yunnan and gave smashing attack on various military posts used by Vietnam for provocation to China at the frontier of China and Vietnam. On February 17, the 
Xinhua News Agency made a declaration at the command of Chinese Government, if nothing was done to prohibit the aggression behavior of Vietnam, then, without doubt, its aggression would endanger peace and stability in Southeast Asia and even the entire Asia. It declared that, "Chinese frontier forces will uphold Chinese frontier after having given a due counterattack on Vietnamese invaders." From February 27, 1979, Chinese frontier forces began to continuously conquered more than twenty Vietnamese cities, towns and strategic locations, such as, LangSon, DongDang, Locbinh, Cao Bang, Fuhe, Qixi, Quảng Uyên, Xialang, Tuolang, Hoa An, Dong Xi, Chong Qing, Cha Ling, Tong Nong, Shuo Jiang, Old street, Gan Tang, Meng Kang, Ba Sa, Sha Ba, $\mathrm{Pu}$ Lou, Guo Can and Feng Tu, etc, which brought a heavy blow to Vietnam and almost attained the anticipated purpose. On March 5, 1979, Chinese frontier forces began to withdraw from the areas stated above. The Xinhua News Agency thus made a statement, "Chinese Government reaffirmed, 'we will not occupy a little bit of Vietnamese land and will, by no means, allow other countries to violate territory of China. What we pursue is a peaceful and stable frontier. We also wish that this just standpoint of Chinese Government would receive respect from Vietnamese Government and governments of the whole world. We would like to request Vietnamese authority not to launch again any armed provocation or invasion in Chinese border after withdrawal of Chinese frontier forces.' The Chinese government made a solemn statement, 'if the above situation appears, China will maintain the right of launching a counterattack in self-defense." By March 16, all of Chinese frontier forces had withdrawn and returned to Chinese border.

Chinese self-defense war heavily attacked the aggression arrogance of Vietnamese regional hegemonism, urged Vietnamese invasion army to recall some troops from Cambodia and supported the anti-Vietnamese war of Cambodian people. After China withdrew its troops, according to the proposal by the Security Council of UN to require China to withdraw from Vietnam and Vietnam to withdraw from Cambodia, Vietnam was denounced by the international society and fell into a passive situation because Vietnam hadn't withdrawn from Cambodia.

\section{China made efforts to peacefully resolve Cambodian issues}

The Chinese government had always been persistently pursuing the Five Principles of Peaceful Coexistence and the principle of safeguarding world peace in its foreign policies. In February 1984, in his interview with the delegation of the Center for Strategic and International Studies in US Georgetown University, Deng Xiaoping said, "there are too many disputes in the world and we have to find a way out. These years, I have always been thinking searching for a method to resolve these issues in a peaceful way without any war."

At the end of 1970s and at the beginning of 1980s, the Chinese Government gave a determined counterattack on implementation of Russia's global strategy and rampancy of Vietnamese regional hegemonism. On January 31, 1979, during the dinner with American journalists in his visit to US, Deng Xiaoping said, "we have such a choice. That is, wherever Russia makes trouble, we will prohibit it and frustrate its making trouble anywhere in the world." As for the issue of Vietnamese invasion in Cambodia, Deng Xiaoping said, "the treaty between Vietnam and Russia is with it the feature of military alliance. Vietnam launched a large scale of armed invasion in Cambodia and provoked Chinese border area. Vietnam played a worse role than Cuba and we call Vietnam eastern Cuba. To deal with such a country, I am afraid that no other means can have any effect than a necessary lesson." This manifested the attitude of the Chinese Government to be determined to oppose to hegemonism and to give a counterattack. On January 29, 1979, in his conversation with Carter, Deng Xiaoping pointed out, invasion of Vietnam in Cambodia "is a serious problem, which is part of Russia's strategic deployment... If we do nothing to such strategic deployment, it may cause great trouble. It has been a long time that Vietnam has had the ambition to set up Indo-Chinese Federation. Considering the entire strategic situation, it is necessary to teach a lesson to the wild ambition of Vietnam." On April 19, 1979 when the Sino-Vietnamese War was over, considering the global strategy, Deng Xiaoping expounded how to teach a lesson to Vietnam. He said, "When I was in US, I said to President Carter to give a lesson to Vietnam. Although our topic was restricted to the scope of Sino-Vietnamese border, we considered neither from the angle of the two countries of China and Vietnam, nor from the angle of Indo-China, but from the perspective of Asia and the Pacific, or from the perspective of the global strategy." On January 16, 1980, at the staff meeting convened by the CPC Central Committee, Deng Xiaoping further pointed out, "we gained a victory both in the aspect of military and politics in the self-defense war, which had had great effect on stabilization of the situation in Southeast Asia and on the struggle against hegemonism and will have effect in the future." Thus, it can be seen that, the self-defense and counterattack of China on Vietnam was also a heavy blow to the global hegemonism of Russia and regional hegemonism of Vietnam.

After the middle of 1980 s, as a result of the international situation, China made a positive adjustment to its foreign policy to promote peaceful settlement of Cambodian issues. 
First of all, China adjusted its policies towards Russia and Vietnam and took the initiative to negotiate with new leaders of Russia and Vietnam to create conditions for settlement of Cambodian issues. In July 1986, the Vietnamese Party and Government Leader Le Duan died of disease and Nguyen, Vanlinh was elected as the General Secretary of the Party Central Committee. Vietnamese Communist Party made significant adjustments to its domestic and foreign policies. Under such a circumstance, on July 1, 1987, Chinese Foreign Ministry put forward suggestions to all parties of Vietnam and Cambodia: the entire troop withdrawal of Vietnam was the key to settlement of Cambodian issues, and it was expected that Vietnam could decide the schedule to withdraw its troops within a short period of time, so that the two countries could come to consensus; after withdrawal of Vietnamese troops, troops of all parties of Cambodia should cease fire; it was wished that the Coalition Government of Democratic Kampuchea and Phnom Penh would set up a four-party interim government, in which Norodom Sihanouk would hold the position of the President, and then a national election was held to set up a national parliament and a new government; China advised the United Nations to set up a supervision institution in Cambodia and observed and supervised the troop withdrawal of Vietnam and national election of Cambodia. China would be willing to protect self-reliance, peace and unification of Cambodia together with the United Nations. In order to resolve the issues of Cambodia, Chinese leaders had an in-depth conversation with Vietnamese leaders and came to an important consensus. On September 2, 1990, the General Secretary Jiang Zemin, and the Prime Minister Li Peng met in Chengdu with the General Secretary of the Central Committee of Vietnamese Communist Party Nguyen, Vanlinh, the Government Prime Minister Dumay and the Consultant of the Central Committee of Communist Party Pham Van Dong who visited China, and had an negotiation about issues of China, Vietnam and Cambodia. After two days' negotiation, leaders of the two countries came to an important consensus, and signed the document of "minutes of the meeting". As for the issues of Cambodia, Vietnamese leaders indicated, people of Vietnam and Cambodia were quite sorrowful for contradictions between the two countries, and they decided to withdraw all troops from Cambodia and recover their traditional friendship. They would also be willing to accept the Framework Document, bring an end to Vietnamese and Cambodian conflicts, make the two countries coexist in peace and step towards a new era. Negotiation between Chinese and Vietnamese leaders plowed the soil for final settlement of Cambodian issues.

At the same time, China also took a positive attitude towards diplomatic activities with Russia. In July 1986, Mikhail Gorbachev said in his speech in Vladivostok, "settlement of Cambodian issues depends on normalization of Sino-Vietnamese relations. Now, it is a favorable opportunity and the entire Asia needs this condition." At the end of August 1988, Rogachev, the Vice Minister of Foreign Affairs of Russia, had a discussion with Tian Zengpei, Chinese Vice Minister of Foreign Affairs, at the level of vice minister of foreign affair on the issues of Cambodia in Beijing. The two countries agreed to settle the issues of Cambodia as soon as possible. At the end of 1988, Deng Xiaoping sent Qian Qichen, the Foreign Minister of China, to visit Russia, and China proposed three suggestions about the issues of Cambodia: China and Russia should come to a consensus about the issue of Vietnamese troop withdrawal and should urge Vietnam to withdraw its troops; after Vietnam withdrew its troops, all foreign powers had to cease their military aid to all parties of Cambodia, and should not support any party engaged in a civil war; China and Russia should the Coalition Government established by the four parties of Cambodia headed by Norodom Sihanouk. On May 16, 1989, Deng Xiaoping had an interview with the visiting Gorbachev. The two came to an agreement about settlement of Cambodian issues and issued a joint declaration.

Then, China motivated the United Nations to hold an international conference to resolve the Cambodian issues and negotiated with US, France and Association of Southeast Asian Nations (ASEAN) to facilitate settlement of Cambodian issues.

In May 1987, Chinese Government invited Javier Perez de Cuellar, Secretary General of the United Nations, to visit China and asked the United Nations to hold an international conference which would be attended by five permanent member states of the Security Council and participated by ASEAN, Vietnam and the four parties of Cambodia. Deng Xiaoping also cordially invited Javier Perez de Cuellar to fly to Hanoi to convey the four suggestions by China to the leader of Vietnam: attack of Vietnam on Cambodia was violation of "Charter of the United Nations", and Vietnam had to withdraw all its troop, cease fire and recover peace; after the international conference came to terms, the United Nations would assign important institutions to conduct supervision and examination within Cambodia, remove internal separation and hold the national general election; Cambodia should, first of all, set up the coalition government of the four parties headed by Norodom Sihanouk, and the power should not be independently wielded by any party. The new government would be established after the national general election; after peaceful settlement of Cambodian issues, relationship between China and Vietnam might come to normal. 
On July 31, 1989, the international conference in Paris to settle the issues of Cambodia was held. Qian Qichen, the Foreign Minister of China, led Chinese representatives to attend the conference. As for settlement of Cambodian issues, Qian Qichen made a speech that, the key to settlement of Cambodian issues was that, firstly, foreign troops had to withdraw all their troops under supervision of the international society, and, secondly, after withdrawal of troops, Cambodia should maintain peace and prevent any civil war to fulfill national reconciliation. Hanoi and Phnom Penh uncompromisingly sticked to their own standpoints, this conference fell on stony ground.

In order to settle the issues of Cambodia, Chinese Government took the initiative to have an interview with other permanent member states of the United Nations and ASEAN to accelerate settlement of Cambodian issues. In 1990, five permanent member states held six talks in Paris and New York and signed the five framework documents about politically settling Cambodian issues, including the general election of Cambodia with the support of the United Nations.

Under powerful push of China, Javier Perez de Cuellar, Secretary General of the United Nations decided to hold a second international conference in Paris on October 20, 1991. Foreign Ministers from 19 countries and leaders of the four parties of Cambodia attended the conference and signed "Agreements on a Comprehensive Political Settlement of the Cambodia conflict", "Agreement concerning the Sovereignty, Independence, Territorial Integrity and Inviolability, Neutrality and National Unity of Cambodia", "Rehabilitation and Reconstruction of Cambodia" and "Final Act". The issues of Cambodia were ultimately settled.

\section{References}

(1975). Chairman Mao Zedong, Chairman Zhu De and Premier Zhou Enlai respetively sent a telegram to Norodom Sihanouk, Premier Pennu and Vice Premier Khieu Samphan. People's Daily, April 18.

(1978). The Chinese Government and Chinese people resolutely supported the just war of anti-Vietnamese expansionists' invasion by Cambodian people. People's Daily, December 7.

(1979). Conversation between Deng Xiaoping and US President Carter. January 29.

(1979). People's Daily. February 2.

(1979). Statement of the Government of the People's Republic of China. People's Daily, January 8.

(1979). Truth of Conflicts at Sino-Vietnamese Border (Dataset). Beijing: People's Publishing House.

(1979). Xinhua Monthly, (3).

(1982). Congratulations to Successful Achievements by the Patriotic Power of Cambodia at the Meeting in Beijing. People's Daily, February 22.

(1982). Manifesto of Establishment of the Coalition Government of Democratic Kampuchea. People's Daily, June 23.

(1986). Eight Suggestions to Support the Coalition Government of Democratic Kampuchea. People's Daily, April 30.

Deng, Xiaoping. (1993). Selected Works of Deng Xiaoping (Vol. 3). Beijing: People's Publishing House.

Deng, Xiaoping. (1994). Selected Works of Deng Xiaoping (Vol. 2). Beijing: People's Publishing House.

Party History Research Center of the CPC Central Committee. (1998). Great Historical Events during the New Period of the Communist Party of China. Beijing: Chinese Communist Party History Publishing House.

Qian, Qichen. (2003). Ten Notes of Diplomacy. Beijing: World Knowledge Publishing Press.

Talk by Deng Xiaoping in His Interview with the Visiting Delegation to China of Foreign Relations Committee of US Senate. April 19, 1979.

Zhang, Qing. (2004). Deng Xiaoping and Peaceful Progress of Cambodia. World Knowledge, (14).

Zhang, Qing. (2004). My Experience of Great Political Settlement of Issues in Cambodia. World Knowledge, (24).

Zhang, Qing. (2005). China's Third Generation Leaders and Cambodia. Around Southeast Asia, (8). 